\title{
耳川下流域の地質構造及び地下水
}

\section{Geological Structure and Ground Water Condition on the \\ Catchment Area of Mimi-kawa River. \\ Masao Nakagawa}

中川雅郎*

\section{1. まえがき}

筆者は福井県三方郡美浜町，耳川下流域において昭和38年〜 40年の各年，主として 8 月に地質構造 ならびに地下水の調査を実施してきた。こつにこれ迄の結果を䌅めて報告する。

2. 耳川下流域の地形及び地質

耳川は嶺南地区東部の地峡部破砕帯中央部にほぶ位置し，三国山西方より北西に流れ若狭湾に注い でいる。下流域の西方には五つの湖沼から成る三方湖沼地帯がある。周囲の山塊は主として古生層及 び花崗岩類である。古生層は主に粘板岩，チャート，砂岩より成り部分的に碟岩，輝緑凝灰岩などを 挾えでいる。又，花岡岩類は主に白雲母花崗岩であるが，一部の地域に Aplite が分布している。こ れらは地表に近い部分ではかなり風化しており，下流域には之らの風化土砂の堆積した比較的厚い洪 積層が分布し，これを沖積層が薄く覆っている。これらの分布を図 1 に示す。

次に耳川沿いとその西方矢筈山麓にそれとほぶ平行 に，更に土井山北辺から北西に伸びる方向に夫々断層 $\mathrm{AB}, \mathrm{CD}, \mathrm{EF}$ があり，いずれも耳川地溝帯の形成 (時 期は下部洪積層堆積末期と推定される）と同時に生じ たものと思われる。河口近くの山地をつくる古生層に は，多くの小規模な断層が見られるが，概ね北東〜南 西に走っている。川の西岸には河成段丘や扇状地の発 達が見られ，東岸にはこの様な地形が見られない。こ の事は上記地溝帯をつくった地殼変動において西岸が 東岸に対して隆起したことを物語っている。

3. 地下地質構造の推定

地質棈造を推定する為に比抵抗法による電気探査を 図 1 に示された28ケ所において実施したが, 各測定点 に対する $\rho-\mathrm{a}$ 曲線及びその解釈の数例を図 2 に示し た。又，地下地質の構造を流域内の測定個所を連結し て数種の断面図を画き図 3 に示した。

基盤を構成する花崗岩ならびに古生層の上に堆積す る洪積層の厚さは，その基盤の起伏によって相異する が, 地溝带に当る部分の特に興道寺付近では非常に厚 く100m〜140mに達する。

4. 带水層と地下水流域

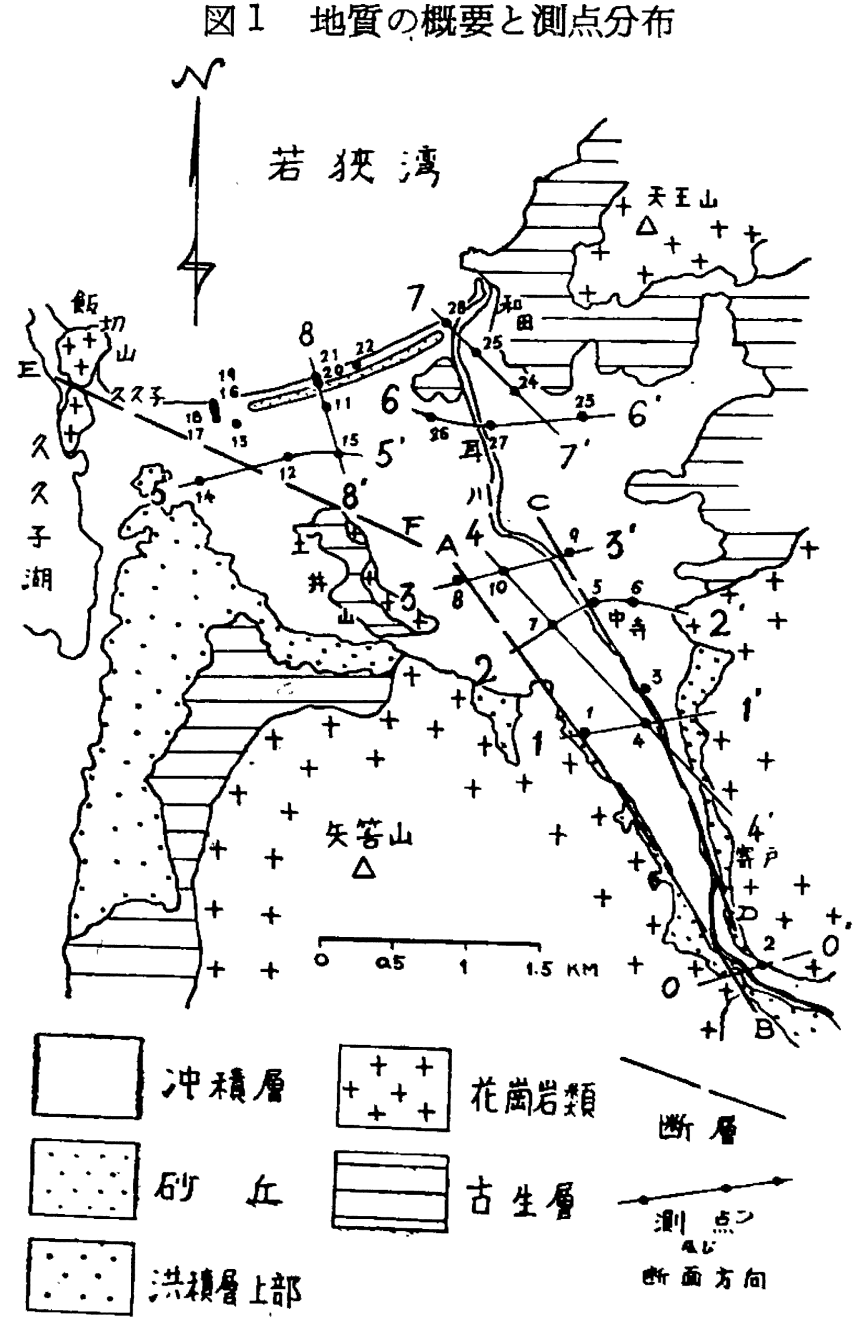

* 京都女子高等学校 
図 $2 \rho-\mathrm{a}$ 曲線と地質構造
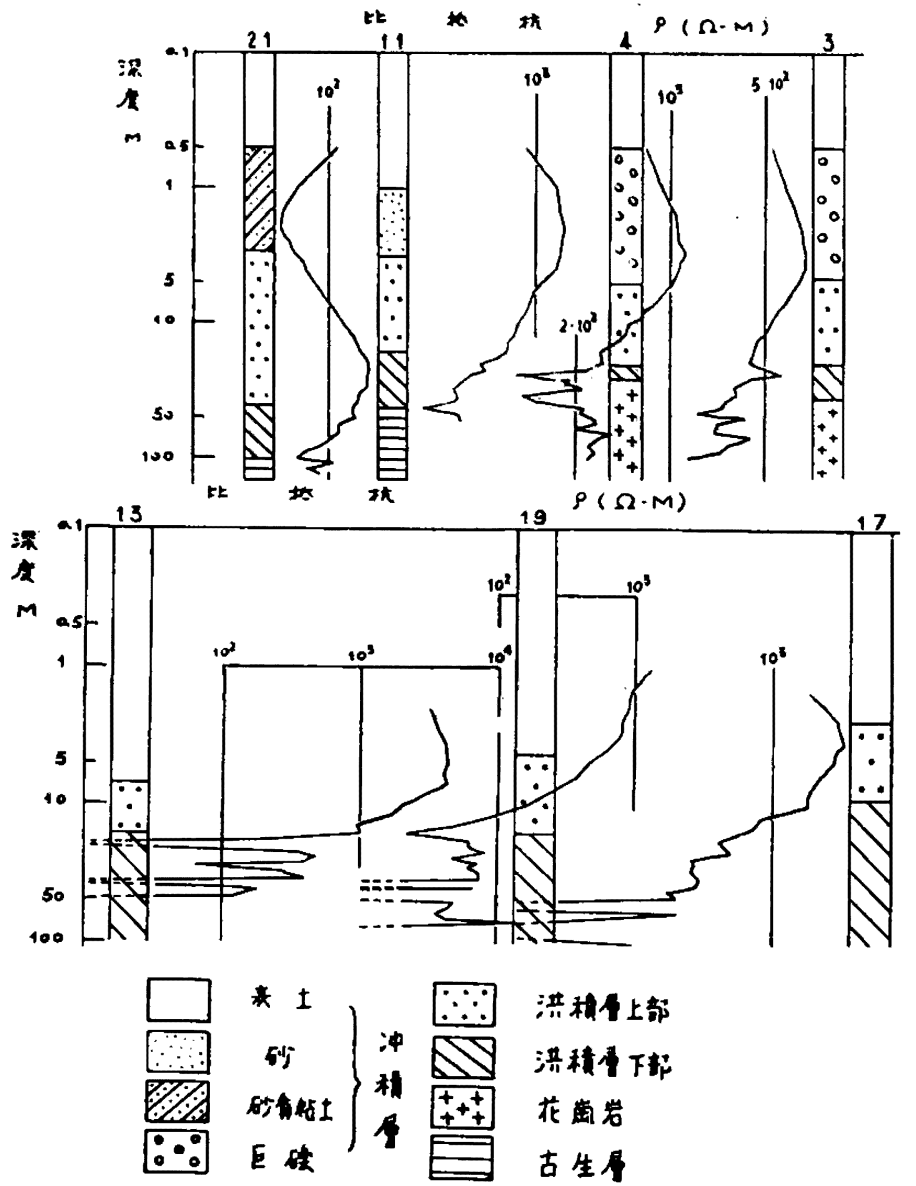

図4 基般の形態と断層 : 断層 $\mathrm{EF}$ に沿うて地下水は一種 の地下水瀑布線を形成しているものと考えられる

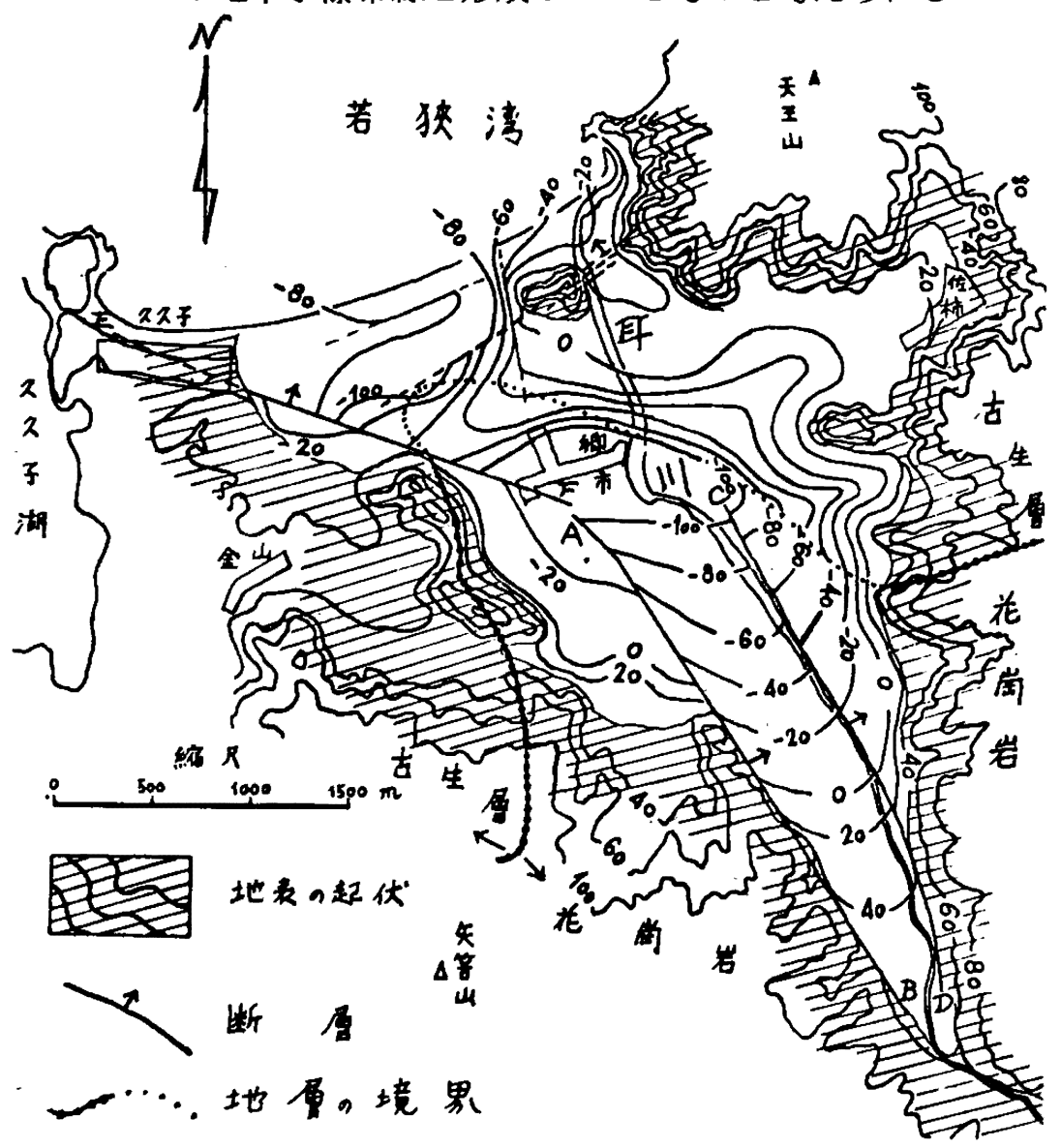

因 3 地質構造推定断面図
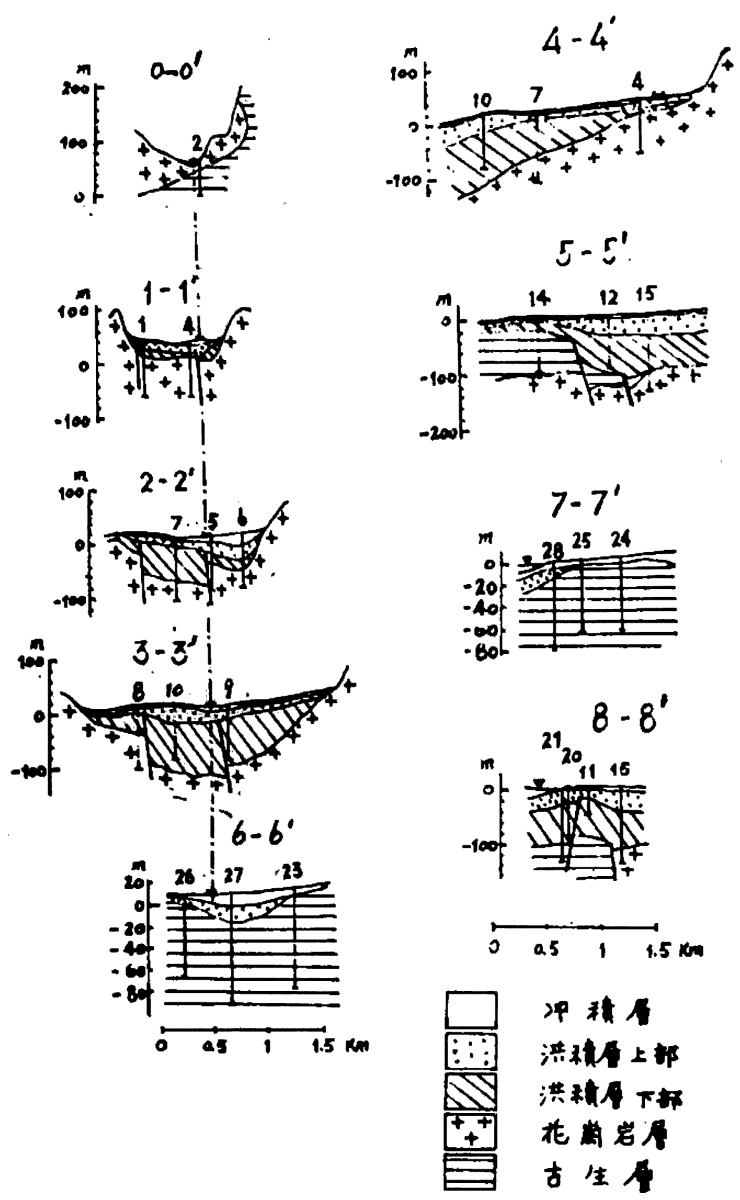

前述の洪積層は上部, 下部の 2 層に 分けられるが, $\rho-\mathrm{a}$ 曲線の変化から察 する上部洪積層は一様な砂(又は細砂) や碟，砂磁からなり，下部洪積層には 粘土層又は粘土質層が多い。これらの 内, 砂質又は砂磁質の多い上部洪積層 は水の唀性の非常に良好な帯水層を 形成している。地表から滲透した降水 の一部は，洪積層を潤して基盤との間 に貯溜され概ね北方に傾斜した基盤面 に沿うて流下すると考えられる。この 場合，花崗岩盤の比較的残い地域にお いては 1.5〜 $2 \mathrm{~m}$ の風化帯が認められ るが殆ど大部分の基盤面は新鮮な状態 にあると考えられ，従って不透水盤で ある。又，古生層も殆ど完全な不透水 盤と考えられるので, 地下水流域はこ の基盤の形態に支配される。基盤の形 態を電気探査による各測定点の基盤表 面の海抜高度の分布にしたがって等高 
線を画いて図 4 に示した。

5. 表流水並に浅層地下水

\section{A . 地下水の流動}

地域内の住区及び工場等の水源は，宮代地区並に新庄地区の一部が簡易水道に依存している他は全 部浅層地下水を利用している。その内地下水自由面を直接観測出来るいわゆるつるべ式井戸を保存し ている処は僅か数個所に過ぎず測水困難な為に，各井戸所有者から得た資料（掘さく深度，改良前の

Table 1

Ground water levels (m)

\begin{tabular}{c|c|c|c|c||c|c|c|c|r}
\hline Station & D & D-h & G. H & W. H & Station & D & D-h & G. H & W. H \\
\hline A & 4.4 & 3.4 & 50 & 46.6 & P1 & 3.8 & 2.8 & 13 & 10.2 \\
B 1 & 7.2 & 5.9 & 47 & 41.1 & P2 & 6.0 & 4.7 & 16.5 & 11.8 \\
B2 & 7.1 & 5.8 & 43 & 37.2 & Q2 & 6.6 & 5.3 & 7.5 & 2.2 \\
C & 9.0 & 7.5 & 43 & 35.5 & Q3 & 5.9 & 4.6 & 5 & 0.4 \\
D & 3.6 & 2.6 & 40 & 37.4 & R 1 & 3.3 & 2.3 & 8 & 5.7 \\
E1 & 5.4 & 4.1 & 35 & 30.9 & R2 & 4.5 & 3.5 & 10 & 6.5 \\
F & 7.2 & 5.9 & 37 & 31.1 & R3 & 2.4 & 1.4 & 2.5 & 1.1 \\
I & 6.9 & 5.6 & 24 & 18.4 & R4 & 3.0 & 2.0 & 8 & 6.0 \\
J 1 & 8.7 & 7.2 & 27.5 & 20.3 & S2 & 3.8 & 2.8 & 10 & 1.2 \\
J 2 & 6.0 & 4.7 & 30 & 25.3 & T1 & 8.1 & 6.6 & 15 & 8.4 \\
J 3 & 9.0 & 7.5 & 26 & 18.5 & T2 & 6.0 & 4.7 & 15 & 10.3 \\
K & 5.7 & 4.4 & 47 & 42.6 & U1 & 2.5 & 1.5 & 2.5 & 1.0 \\
L & 3.0 & 2.0 & 25 & 23.0 & U2 & 6.0 & 4.7 & 6 & 1.3 \\
M & 3.0 & 2.0 & 14 & 12.0 & U3 & 5.7 & 4.4 & 5 & 0.6 \\
N1 & 9.0 & 7.5 & 16 & 8.5 & U4 & 3.0 & 2.0 & 5 & 3.0 \\
N2 & 6.0 & 4.7 & 12.7 & 6.0 & X & 3.9 & 2.9 & 7.5 & 4.6 \\
N3 & 9.0 & 7.5 & 12.6 & 5.1 & Y & 7.0 & 5.7 & 8 & 2.3 \\
O & 6.0 & 4.7 & 15 & 10.3 & & & & & \\
\hline
\end{tabular}

因 5 表流水並に地下水の測定分布

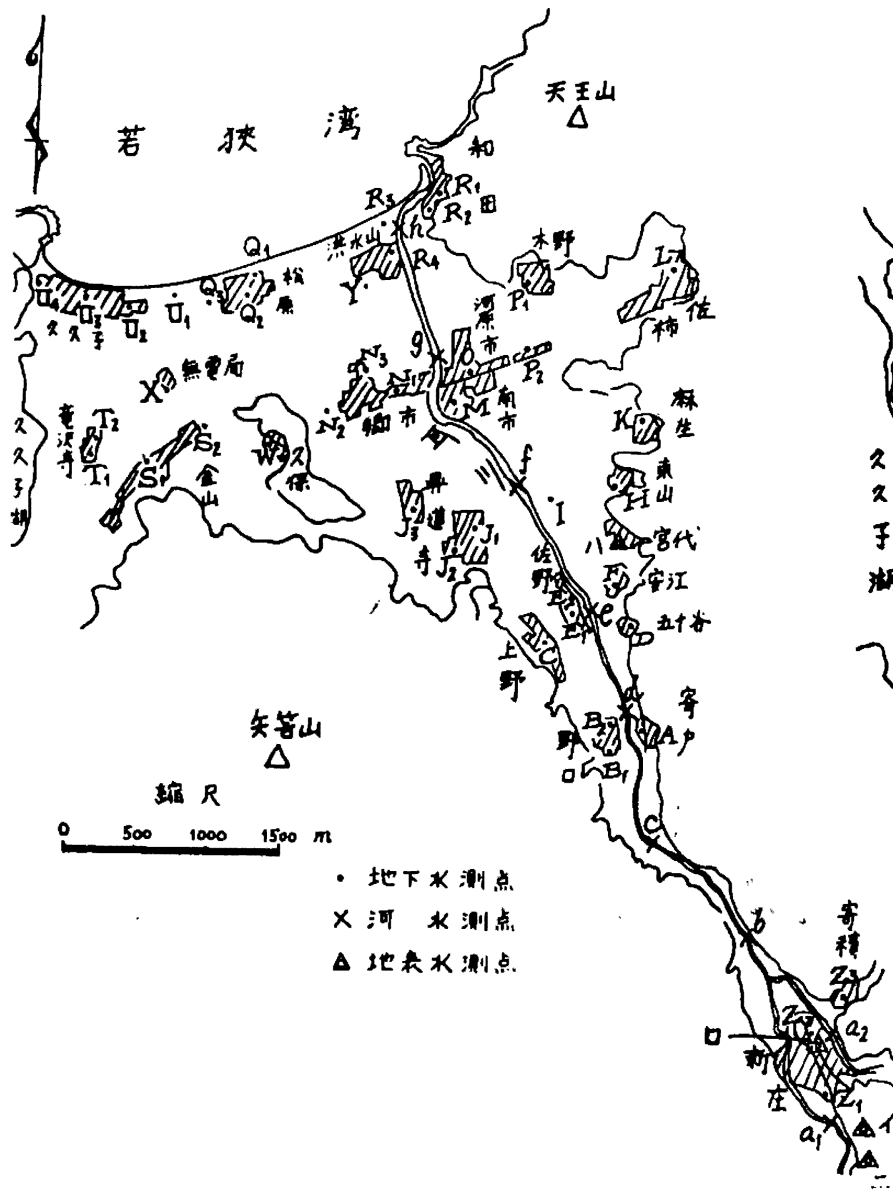

表・1 地下水位

但し D : 掘さく深度

$\mathrm{h}:$ 井底からの地下水面高 度

$\mathrm{G} \cdot \mathrm{H}$ : 地盤海抜高度 $\left(\frac{1}{25,000}\right.$ の地形困から読みとった）

$\mathrm{W} \cdot \mathrm{H}$ : 地下水面海抜高度

地下水面の地表からの深度は, 山 麓部では一般に梁く6〜8 $\mathrm{m}$, 他の 平坦部で $1.5 \sim 5 \mathrm{~m}$ と浅い。しかも地 下水面の梁い山簏部では一般に地下 水位の変動が大きい傾向がある。

図 6 地下水等水位線図

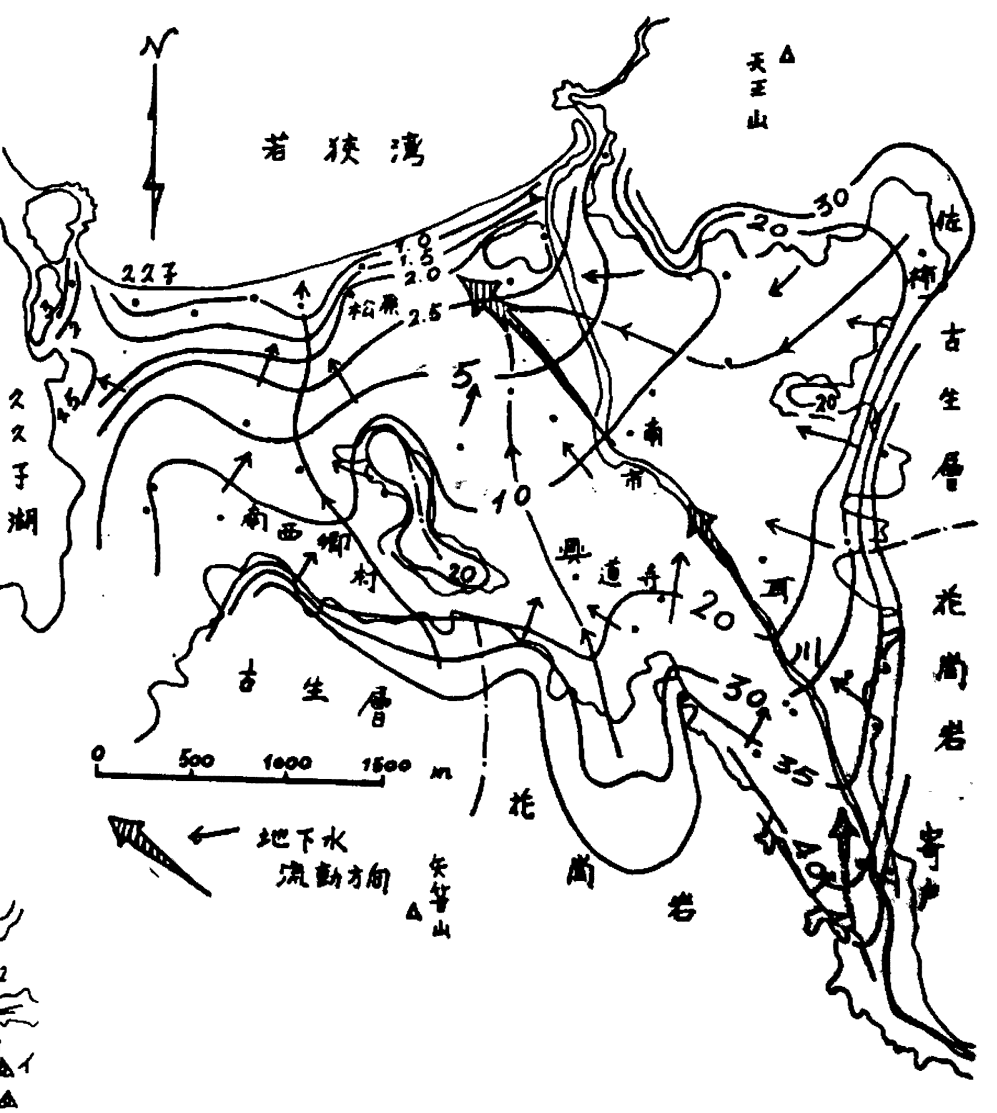


地下水位及びその変動状況等）を基礎として本年観測時期における地下水位を推定して，地下水面の 概要を得た（表・1，図6)。

上の結果より考察すれば，概ね地下水は地表の形態と同様の傾斜をなして流れることを示している と云える。その主流はほぼ耳川に沿って流れるが，南市付近から大部分伏流となって耳川の西方を松 原地区東方に流下するものと考えられる。

図 7 塩素イオン含有量 $(\mathrm{mg} / \mathrm{L})$ 分布図
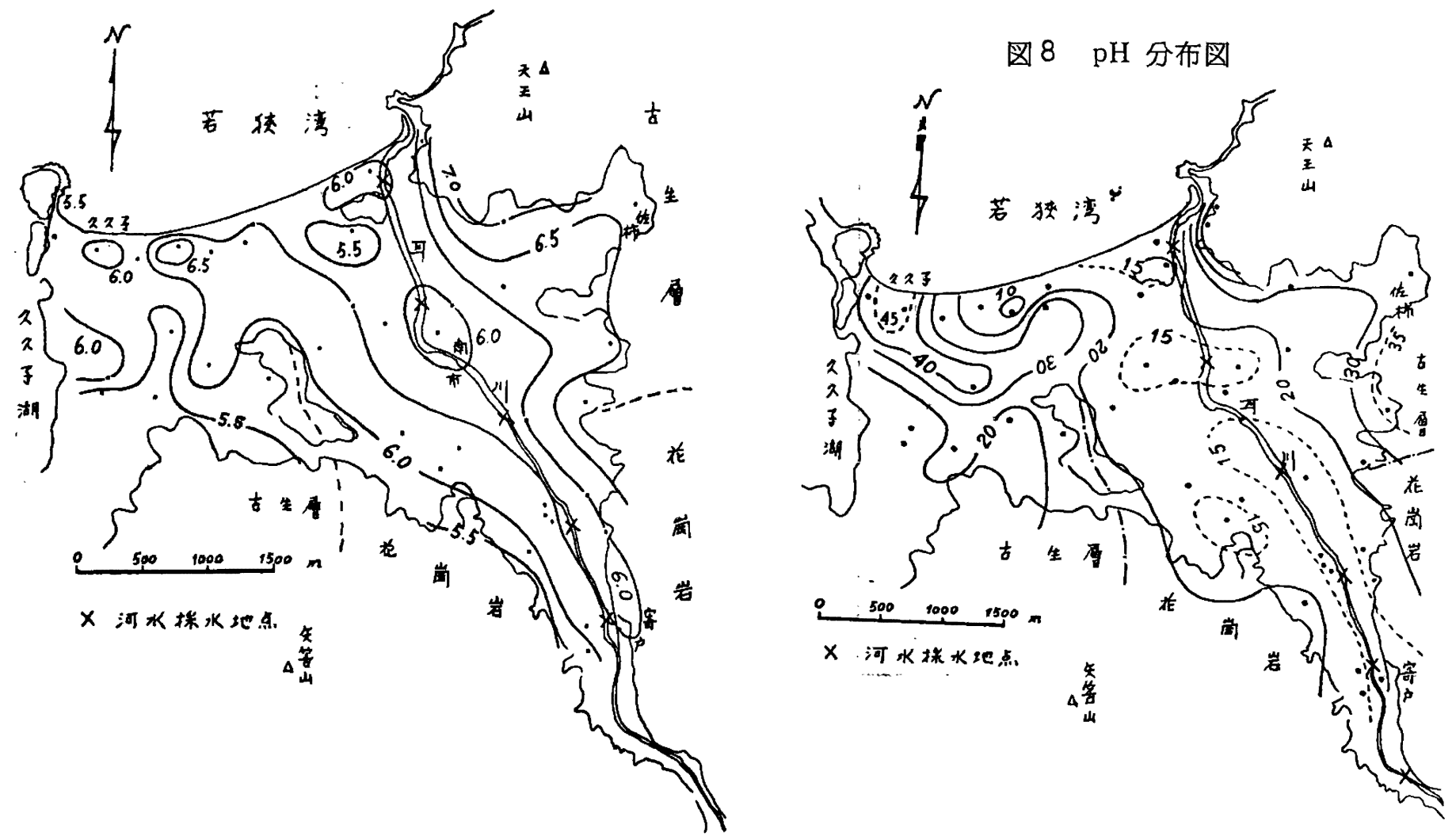

B. 含有塩分及び $\mathrm{pH}$ の水平分布と地下水系

河水並に地下水の塩素イオン含有量と $\mathrm{pH}$ の分布を図 7 ，図 8 及び表・ 2 に示す。

〈含有塩分〉

河水では8.8〜11.0mg/L で上流から下流に向う程多くなっている（図 9)。又，地下水については 御岳山簏部宮代地区から天王山麓部にかけて $30 \sim 58 \mathrm{mg} / \mathrm{L}$ と多く, 久々子地区及びそれから南東に伸 図 9 河水に拈ける $\mathrm{Cl}^{-}$並に $\mathrm{pH}$ の変化

\section{River Flow}

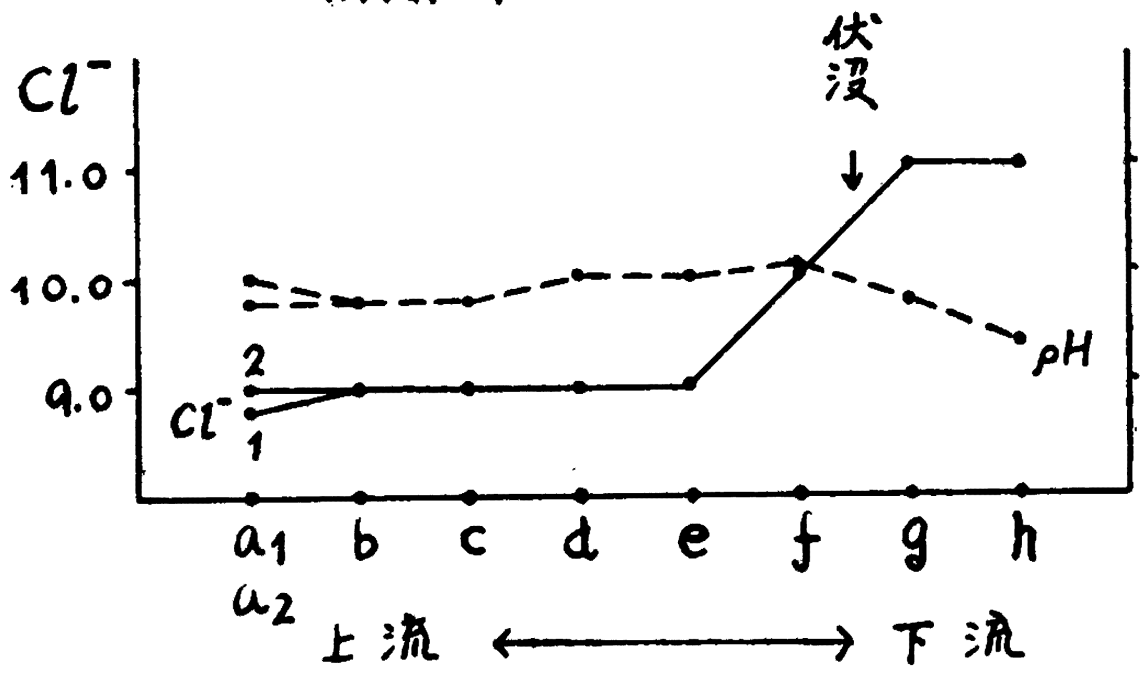

びる一帯も30〜48mg/L とや はり多い。その他の地域は10 pH 〜20mg/L と少なくなってい 8.0

7.0 6.0 又後者の場合は人為的污染及 び地下地質構造による塩水混 入に主な原因があると考えら れる。

$\langle\mathrm{pH}\rangle$ 
Table 2. Quality of Ground Water

Aug. 21-26, 1965.

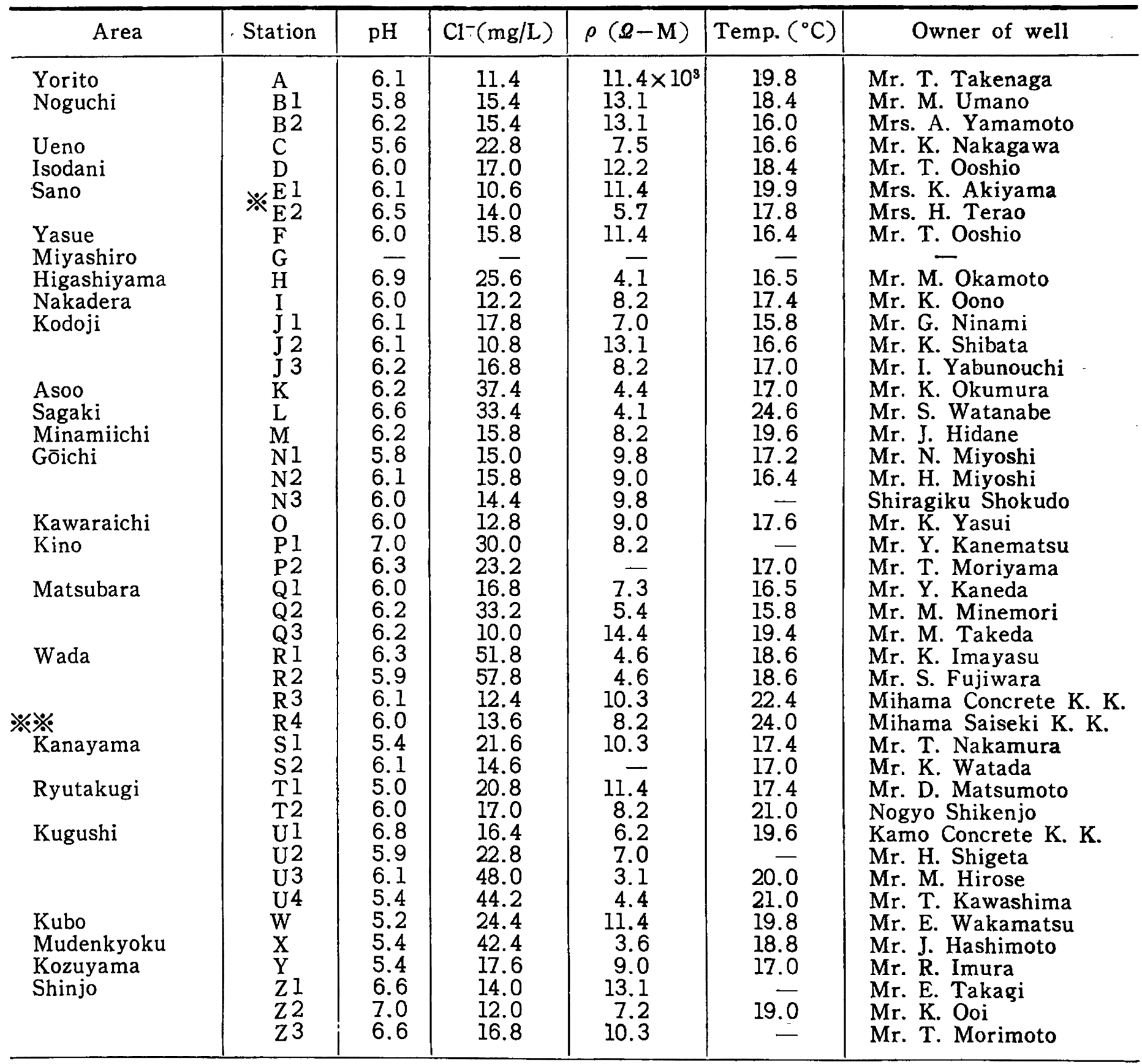

Table 2-2. Quality of River Flow

\begin{tabular}{|c|c|c|c|c|c|c|}
\hline Station & $\mathrm{pH}$ & $\mathrm{Cl}^{-}$ & $\rho$ & Temp. & & \\
\hline a $I$ & 6.8 & 8.8 & 15.4 & 20.0 & & \multirow{9}{*}{ 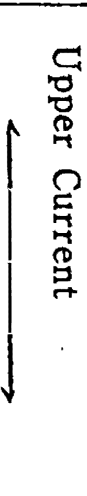 } \\
\hline a 2 & 7.0 & 9.0 & 11.4 & 20.2 & & \\
\hline b & 6.8 & 9.0 & 15.4 & 20.1 & & \\
\hline c & 6.8 & 9.0 & 14.4 & 21.1 & & \\
\hline $\mathrm{d}$ & 7.0 & 9.0 & 14.4 & 21.8 & & \\
\hline e & 7.0 & 9.0 & 14.4 & 22.1 & & \\
\hline $\mathrm{f}$ & 7.1 & 10.0 & 13.1 & 22.5 & & \\
\hline $\mathrm{g}$ & 6.8 & 11.0 & 12.2 & 26.6 & & \\
\hline $\mathrm{h}$ & 6.4 & 11.0 & 13.1 & 25.6 & & \\
\hline
\end{tabular}

Table 2-3. Quality of Surface Flow

\begin{tabular}{c|c|r|r|c}
\hline Station & $\mathrm{pH}$ & \multicolumn{1}{c|}{$\mathrm{Cl}^{-}$} & $\rho$ & Temp. \\
\hline 1 & 5.7 & 9.0 & 14.4 & - \\
$\square$ & 5.9 & 8.8 & 11.4 & - \\
$\therefore$ & 6.8 & 14.8 & 13.1 & - \\
$=$ & 6.8 & 9.0 & 9.8 & - \\
\hline
\end{tabular}

$※ \mathrm{E}_{2}$ 点の地下水より Gallionella を検出

※※ 金山地区に小規模な涌水（現地ではこれを 清水〔しょうず〕と呼び，昔から共同水源 として利用)がある 
】河水の $\mathrm{pH}$ は殆ど $\mathrm{RpH}$ に近いと考えられるが，6.4〜7.1の範囲で概ね上流から下流に向って次第 にアルカリ性化している。しかし，前述の主流伏没点付近から下流では逆に酸性化している(因 9 )。 又, 地下水については矢筈山の北麓と洪水山南方の地域が5.0 5.5と酸性を示し, 御岳山麓部宮代地 区から天王山麓部にかけて6.5〜7.0と中性乃至弱酸性を示している。その他は 5.5〜6.0 の範囲を示 している。これらの地域的差異は地質構成状況を反映している様である。

$\left\langle\mathrm{Cl}^{-}, \mathrm{pH}\right.$ の分布と地下水系〉

$\mathrm{Cl}^{-}, \mathrm{pH}$ の分布状況に先の地下水流動状況を考え合わせて，大要次の様なことが云える。即ち， 供給源の異なる三つの地下水系がある。(1) M水系 調査地域の最も重要な水系でその主流はほよ゙耳 川に沿っている。特徵としては, $\mathrm{Cl}^{-}$は絶対量少なく流動と共にその量を増し, $\mathrm{pH}$ は流動と共に次 第にアリカリ性化する傾向がある。(2) Y 水系 矢筈山から北に流れ， $\mathrm{Cl}^{-}$絲対量多く，流動と共 に増大ししかも濃度変化の割合が大きい。又， $\mathrm{pH}$ は流動と共にアルカリ性化する傾向がある。(3) $\mathrm{O}$ 水系 御岳山一天王山地域から西に流れ, $\mathrm{Cl}^{-}$は絶対量多く流動と共に減少, 又 $\mathrm{pH}$ は次第に酸性 化する傾向があって，いずれも $\mathrm{M} ， \mathrm{Y}$ 両水系とその傾向が逆である。

次に全地域の地下水の $\mathrm{Cl}^{-}-\mathrm{pH}$ 相関グラフを図10に示す。それによれば，概して $\mathrm{Cl}^{-}$の増大と共 に地下水は酸性化しているが，地層構成物質の化学的諸性質等の相互の関連を考えてみなければその 実態はつかめない。又, このグラフの特徴から地下水を二群に大別することが出来る。 $\mathrm{M}$ 及び $\mathrm{Y}$ 水 系の大部分は第 I 群に，O水系の殆どが第 II群に属している。しかも O水系については，地点による $\mathrm{Cl}^{-}$の量的差異が大きい。

図10 Cl と $\mathrm{pH}$ の相関

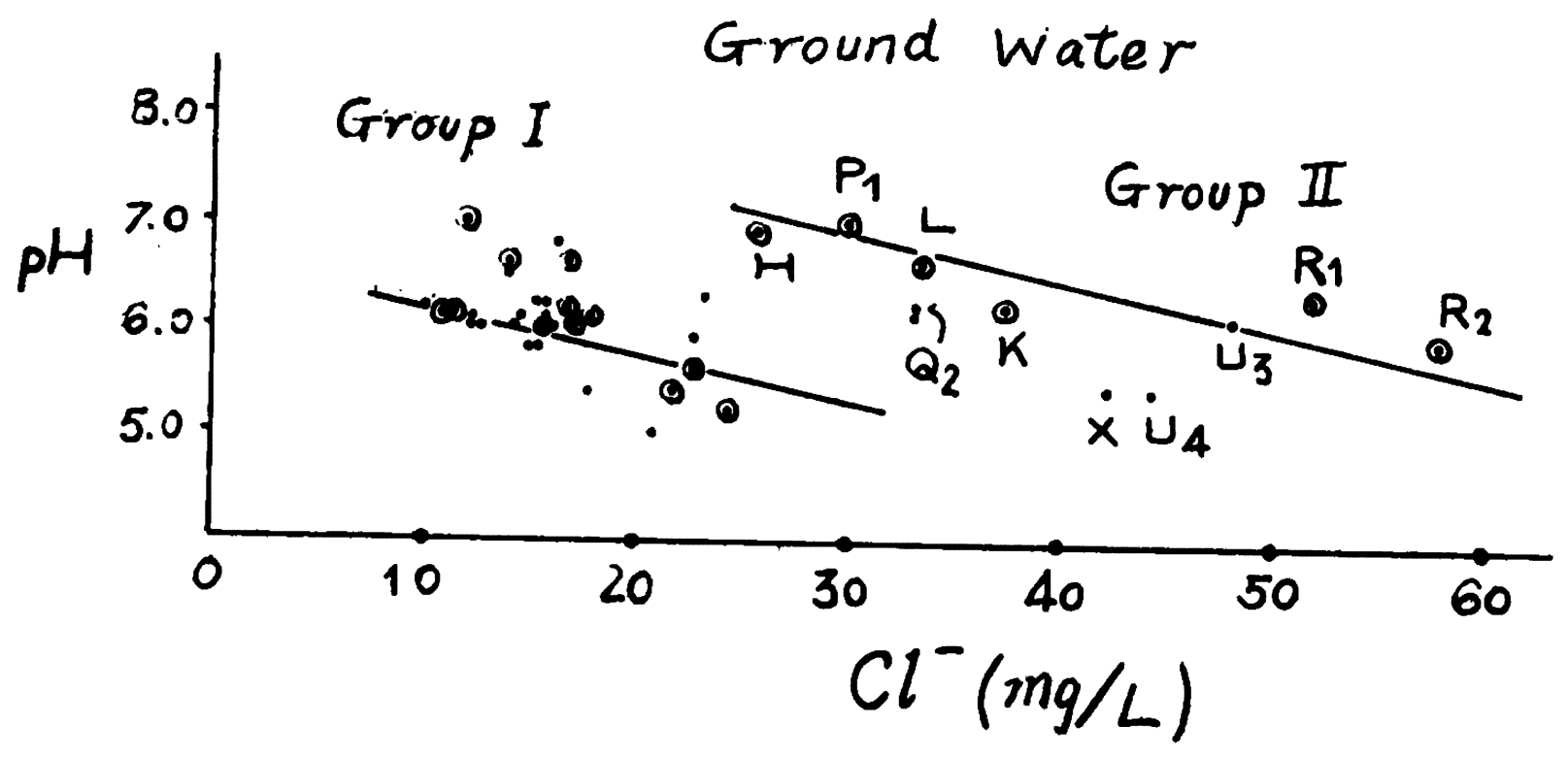

- 平地部地下水 $\bigcirc$ 山管部地下水

M水系, Y水系は Group I $(\mathrm{pH}=6.6-0.44 \mathrm{Cl})$ に属し，

O水系は Group II ( $\mathrm{pH}=8.2-0.44 \mathrm{Cl})$ に属する

結語

本地域においては, 地下水の工業, 農業面の利用は殆ど進えでいないが, 将来多面的開発の期待さ れるところと思われる。なお, 今後賦存量の算定の為の調査を行ない, 利用開発の面から更に研究を 進めていく考えである。 